\title{
Acid digestion on river influenced shelf sediment organic matter: Carbon and Nitrogen contents and isotopic ratios
}

\author{
Pasquier Virgil ${ }^{1,{ }^{*}}$, Sans Jofre Pierre ${ }^{1}$, Lebeau Oanez ${ }^{2}$, Liorzou Celine ${ }^{1}$, Rabineau Marina ${ }^{3}$
}

${ }^{1}$ UMR 6538, Laboratoire Géosciences Océan; Institut Universitaire Européen de la Mer; rue Dumont d'Urville 29280 Plouzané France

${ }^{2}$ Institut Universitaire Européen de la Mer, Université de Bretagne Occidentale, CNRS UMS 3113;

Place Nicolas Copernic 29280 Plouzané France

*Corresponding author : Virgil Pasquier, email address : virgil.pasquier@univ-brest.fr

\begin{abstract}
:
Rationale

Natural stable isotopes ratios ( $\mathrm{d} 13 \mathrm{Corg}$ and $\delta 15 \mathrm{~N}$ vales) and associated elemental concentrations (i.e. total organic carbon and total nitrogen contents) preserved in marine sediments are frequently used for the determination of paleoenvironmental processes such as the origin of organic matter. Previous studies highlighted biases in the determination of such geochemical proxies due to pre-analysis acid treatment methods. This study is the first systematic comparison of the effect of acid treatment methods on bulk organic matter using a unique sedimentary system, under two contrasting climatic contexts (i.e. glacial vs interglacial).
\end{abstract}

Methods

We used the most common method for pre-treatment analysis, which consists of the acidification of bulk sediments followed by several de-ionised water rinses. We investigated the effect of acid type (hydrochloric acid and acetic acid), and also acid strength (from 0.2 to $10 \mathrm{~mol} \mathrm{L-1}$ ) on the $\delta 13$ Corg, $\delta 15 \mathrm{~N}, \mathrm{TOC}, \mathrm{TN}$ and $\mathrm{C} / \mathrm{N}$ values of three samples from the Gulf of Lion. Two of them (S302 and S102) were deposited during glacial maxima (i.e. high sedimentation rate, low porosity and high terrestrial inputs) whereas S157 characterizes interglacial conditions (high porosity, high foraminifera content, low sedimentation rates and low terrestrial inputs).

Results

For all three samples the $\delta 13$ Corg values are between -21.7 and $-24.4 \%$ with the TOC varying from 0.56 and $0.84 \% \mathrm{wt} / \mathrm{wt}$. The $\delta 15 \mathrm{~N}$ values are more stable with an average value of $3.0 \pm 0.1 \%$ with a TN average of $0.08 \pm 0.002 \%$ wt/wt. 


\section{Conclusions}

We show that acid type did not significantly affect results. We also find that (i) glacial and interglacial samples do not react similarly to acid pre-treatment, (ii) high acid strength (>1.5 mol L-1) induces significant bias on $\delta 13$ Corg and TOC values, and therefore on $\mathrm{C} / \mathrm{N}$ ratios; (iii) $25 \%$ of an isotopically distinct pool of organic carbon was lost when using acid concentrations of $0.2-1.5 \mathrm{~mol} L-1$, affecting $\delta 13$ Corg values by more than $1.5 \%$; and (iv) geochemical evidence indicates that the leachable organic carbon pool is preferentially composed of terrestrial organic matter. These findings call for precautions when using $\mathrm{C} / \mathrm{N}$ ratios and associated $\delta 13 \mathrm{Corg}$ values for paleoenvironmental and climate reconstructions.

Keywords : $\delta 13$ Corg, TOC, C/N ratio, organic matter, decarbonatation, pre-analysis treatment method 
Introduction

Sedimentary organic matter $(\mathrm{OM})$ in marine environments is typically composed of a mixture of in-situ marine and land exported particles. Autochthonous grains derive from land erosion, land plant detritus and outcropping older marine deposits which have already been degraded to various degrees. The accurate determination of past total organic carbon content (TOC), total nitrogen content (TN), carbon and nitrogen isotopic composition $\left(\delta^{13} \mathrm{C}_{\text {org }}\right.$ and $\delta^{15} \mathrm{~N}_{\text {tot }}$ values) of $\mathrm{OM}$ naturally preserved in coastal marine sediments has been widely used for past environmental processes interpretation. $\mathrm{C} / \mathrm{N}$ ratios are commonly used as a tracer for $\mathrm{OM}$ sources and alteration during weathering processes (1-5). Combined with $\delta^{13} \mathrm{C}_{\text {org }}$ values, the $\mathrm{C} / \mathrm{N}$ ratio is also a powerful proxy to discriminate carbon sources and different photosynthetic pathways (e.g. C3- vs C4-photosynthesis (6)). Nitrogen isotope ratios and content allow determination of trophic levels but they can also be used as proxy for primary productivity and redox state of past environments (7-11).

In most coastal sediments, the carbon fraction is commonly divided in two forms: organic carbon (OC) and inorganic carbon (IC) which is usually enriched in ${ }^{13} \mathrm{C}$ relative to OC because of the isotopic fractionation induced by photosynthesis (12). The accurate determination of OC content and its carbon isotopic composition involves the complete removal of the IC fraction from the bulk sediment. This is performed using acid treatment methods, which may also introduce artificial modifications of the natural OC mix preserved in old sediments.

There are several studies which have investigated the effects of acid types on specific terrestrial or aquatic products with contradictory induced effects (13-17). Several fundamentally different acid pre-treatment methods have been reported, employing a range of acid reagents and strengths, types of Elemental Analyser capsules (tin or aluminium) or chemistry environment (i.e. wet or fumigation chemistry). The results of these studies show that the acidification step can influence the elemental and isotopic composition of both $\mathrm{C}$ and $\mathrm{N}$, and therefore their subsequent interpretations. Brodie and collaborators $(13,14)$ have shown that nonlinear and unpredictable biases on OM characterization can be related to the acid pre-treatment. Loss or gain of $\mathrm{C}$ and $\mathrm{N}$ appear to vary according to acidification type, characteristic of the depositional environment and IC content (18). Therefore, there is no consensus on the effect of such essential pre-analyses treatments, which is 
commonly considered as negligible or within the instrumental precision. For $\delta^{13} \mathrm{C}_{\text {org }}$ values, shift down to $-7 \%$ have been reported (13), ruling out the possibility of distinguishing between $\mathrm{C} 3$ and C4 photosynthetic pathways. Therefore, environmental interpretation of $\mathrm{OM}$ data in both modern and paleoenvironments can be highly questionable.

This paper presents the first systematic comparison of the most common acid treatment, IC removal using both hydrochloric and acetic acid of a wide range of acid strength on quaternary sediments. We examine the effect of increased acid strength on the reliability of TOC, TN, C/N ratio, $\delta^{13} \mathrm{C}_{\text {org }}$ and $\delta^{15} \mathrm{~N}$ values for three samples from the Gulf of Lion (Western Mediterranean Sea).

\section{Experimental}

\subsection{Samples origin and paleo-climatic context}

The studied sediment originate from the Gulf of Lion (GoL), which is characterised by a wide continental shelf $(70 \mathrm{~km})$, that was sub-aerially exposed during Quaternary glacial times $(19,20)$. The spatial and temporal distribution of sediment in the studied area is mostly governed by sea level changes (Figure 1). The present day spatial composition of OM in the GoL has already been studied in detail (1-3) showing that origin and spatial distribution of $\mathrm{OM}$ are strongly related to sediments deposited at river mouths. These pro-deltaic sediments are characterized by low $\delta^{13} \mathrm{C}_{\text {org }}$ values (around $-25 \%$ ) and high sedimentation rates (i.e. $20 \mathrm{~cm}$.years 1, (21)), contrasting with open ocean sedimentation (i.e. very low sedimentation rate, below $\left.0.3 \mathrm{~m} \cdot \mathrm{ka}^{-1},(26)\right)$ characterized by higher $\delta^{13} \mathrm{C}_{\text {org }}$ values around $-21 \%$ at the shelf break (originating from primary producers and derived outcomes). Depending on the shelf distribution, organic carbon isotope ratios $\left(\delta^{13} \mathrm{C}_{\text {org }}\right.$ values) preserved in sediments can be interpreted as reflecting the relative proportion of terrestrial versus marine OC (i.e. seaward dilution; Pasquier et al, in preparation).

The samples come from the PRGL $1-4$ borehole $(42.690 \mathrm{~N} ; 3.838 \mathrm{E})$, a $300 \mathrm{~m}$ continuous record drilled on the upper slope (298 meters water depth) of the GoL, on the interfluve between the Bourcart and Herault canyons. Borehole PRGL 1-4 was drilled in the framework of the European Union project PROMESS1 (http://www.pangaea.de/Projects/PROMESS1/). Whatever the climatic context (i.e. 
glacial or interglacial), GoL sediments are significantly rich in carbonates (> 40\% $\mathrm{wt} / \mathrm{wt}$ ), and mainly composed of silty-clay sediments, which are poor in organic compounds $(0.6 \%$ and $0.08 \% \mathrm{wt} / \mathrm{wt}$ for Total Organic Carbon (TOC) and Total Nitrogen (TN), respectively, $n=382$ analyses; 22, Pasquier et al, in preparation).

According to the age model (22) and the paleoenvironment reconstructions, the present study is based on 3 samples originating from two contrasted climatic and sedimentological settings:

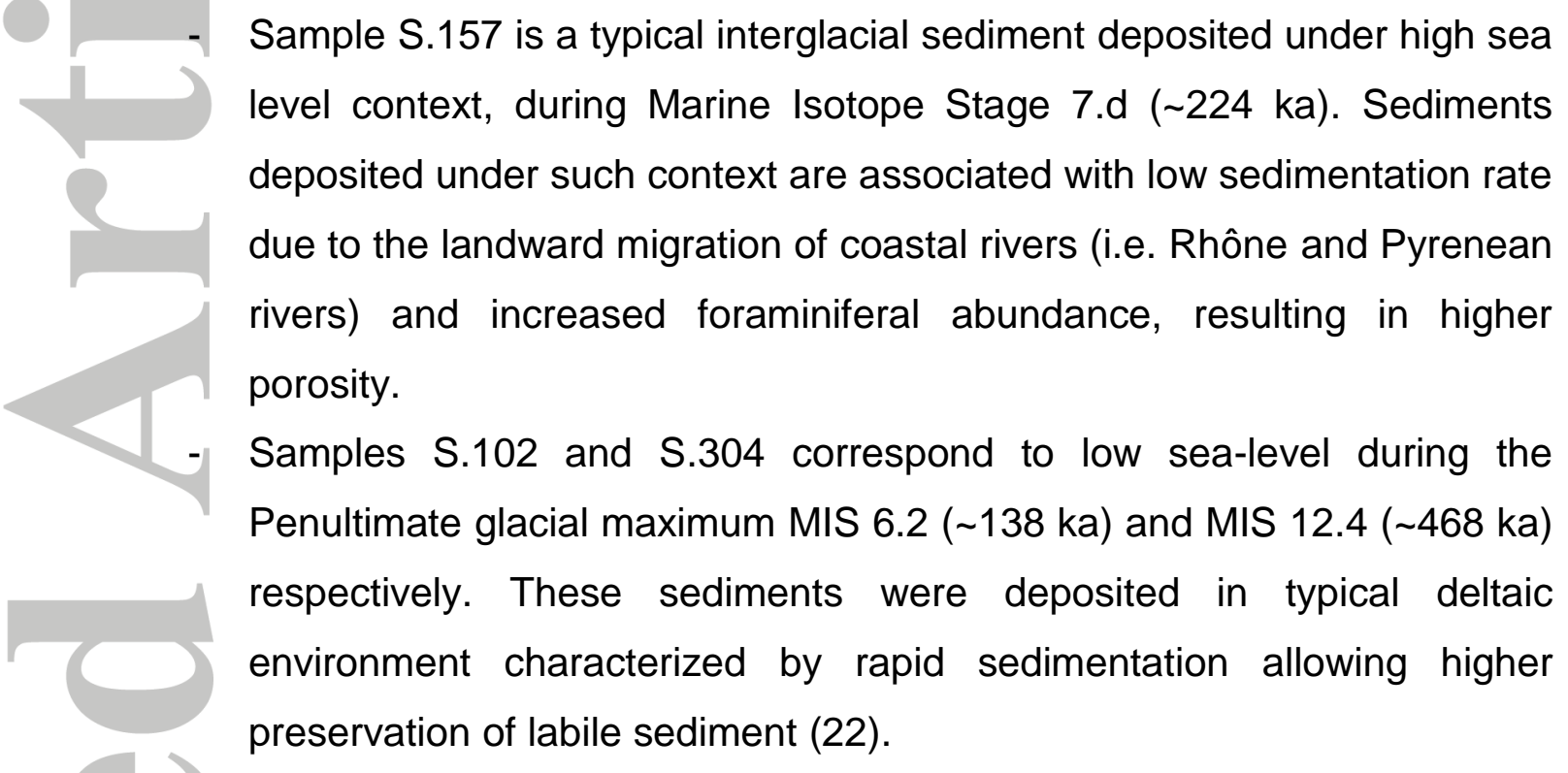

Sample S.157 is a typical interglacial sediment deposited under high sea level context, during Marine Isotope Stage $7 . d$ ( 224 ka). Sediments deposited under such context are associated with low sedimentation rate due to the landward migration of coastal rivers (i.e. Rhône and Pyrenean ivers) and increased foraminiferal abundance, resulting in higher porosity.

Samples S.102 and S.304 correspond to low sea-level during the Penultimate glacial maximum MIS 6.2 ( 138 ka) and MIS 12.4 ( 468 ka) respectively. These sediments were deposited in typical deltaic environment characterized by rapid sedimentation allowing higher preservation of labile sediment (22).

\subsection{Pre-analyses protocol and acid treatment}

Once the borehole has been subsampled, sediments were freeze-dried prior to any treatment. A well-known portion of dried samples $(1.5 \pm 0.1 \mathrm{~g})$ was ground in agate mortar, and transferred to pre-cleaned $15-\mathrm{mL}$ centrifuge tubes. Prior to elemental and isotopic analyses, the carbonate (IC) fraction was removed by dissolution, using an excess of hydrochloric acid $(\mathrm{HCl})$ or acetic acid $(\mathrm{AA})$ for 24 hours at room temperature. In detail, the homogenized sediments were split into numerous aliquots of $30+/-0.5 \mathrm{mg}$. Seventeen different leaching procedures were employed, using $\mathrm{HCl}$ or $\mathrm{AA}$ at different acid strength: $0.2,0.5,1,1.5,2,2.5,3,4,5$, $6,7,8,9,10 \mathrm{~mol} \mathrm{~L}^{-1}, 10 \mathrm{~mol} \mathrm{~L}^{-1}$ (and $2 \mathrm{~h}$ at $80^{\circ} \mathrm{C}$ ), 0.87 and $1.74 \mathrm{~mol} \mathrm{~L}^{-1} \mathrm{AA}$, corresponding to $5 \%$ and $10 \% \mathrm{AA}$, respectively. During digestion, centrifuge tubes were placed in an ultrasonic bath for $3 \mathrm{~h}$ at room temperature to increase the mechanical separation of clay and calcium carbonates. After digestion, the residues were washed three times with distilled water, centrifuged and dried at $50^{\circ} \mathrm{C}$ overnight. The samples were then weighed in tin capsules and kept in a desiccator. 


\section{3. $\quad \mathrm{C}$ and $\mathrm{N}$ elemental and isotopic analysis}

All analyses were performed using an elemental analyser (EA, Flash 2000 Thermo Scientific, Bremen, Germany) coupled to a Delta $V_{+}$isotope ratio mass spectrometer (Thermo Scientific) at the Pôle de Spectométrie Océan (PSO, Brest, France). Samples were first loaded into an autosampler then dropped automatically into the oxidation furnace maintained at $1020^{\circ} \mathrm{C}$. The flash combustion was performed using an 8 second injection time of dioxygen at a flux of $240 \mathrm{~mL} / \mathrm{min}$. The oxidation reactor was filled with chromium(III) oxide and silver-plated cobalt oxide to ensure the complete oxidation of the flash combustion products. The resulting gas was then transferred, by continuous helium flow $(100 \mathrm{~mL} / \mathrm{min})$, to a reducing column filled with activated copper, heated at $650^{\circ} \mathrm{C}$. This reducing step allow both the removal of excess oxygen and the reduction of $\mathrm{NO}_{x}$ to $\mathrm{N}_{2}$. Water vapour was removed from the gas stream by an anhydrous $\mathrm{Mg}\left(\mathrm{ClO}_{4}\right)_{2}$ trap, and the remaining gas phases were separated by gas chromatography and introduced into the mass spectrometer via a Conflo IV interface (Thermo Scientific).

Carbon and nitrogen isotopes ratios were obtained against reference standards SED-IVA (IVA reference number: 33802151) and in-house standards (Acetanilide: $\mathrm{CH}_{3} \mathrm{CONHC}_{6} \mathrm{H}_{5}$ reference number: 274462 provided by Thermo Fisher, CAP: leaf litter and LIPG: yeast from the Institut de Physique du Globe de Paris, Paris, France). The in-house standards were calibrated against certified materials, such as IAEA-N1, IAEA-N2, IAEA-CH6 and IAEA-600 provided by the International Atomic Energy Agency (IAEA, Vienna, Austria). The $\delta^{13} \mathrm{C}_{\text {org }}$ and $\delta^{15} \mathrm{~N}$ values are given as the per mil deviation from the PDB standard and atmospheric $\mathrm{N}_{2}$, respectively. Routine replicate measurements on standards had internal deviations of $\pm 0.15 \%$ and \pm $0.30 \%(2 \sigma)$, respectively, for nitrogen and carbon. The TN and TOC percentages were measured using the Thermal Conductivity Detector (TCD) of the Flash 2000. Routine replicate measurements had internal deviations of less than $4 \%$ and $5 \%$, respectively, for TN and TOC.

\section{Results}

\subsection{Organic Carbon: content and isotopic results}

For all samples (i.e. including all the experiments), the TOC is between 0.56 and $0.84 \% \mathrm{wt} / \mathrm{wt}$ and the isotope ratios between -21.7 and $-24.4 \%$. These values are 
in the classic range of organic-poor sediments deposited in coastal marine environments (22) .

The Inter Glacial sample, S157, has an average $\delta^{13} \mathrm{C}_{\text {org }}$ value of $-22.04 \pm$ $0.13 \%$ with a TOC of $0.79 \pm 0.03 \% \mathrm{wt} / \mathrm{wt}$. No trend nor deviation was observed with the use of different acid treatments.

The Glacial samples, S304 and S102, show average $\delta^{13} \mathrm{C}_{\text {org }}$ values of $-24.62 \pm$ $0.31 \%$ and $-24.31 \pm 0.33 \%$, respectively, and TOC of $0.63 \pm 0.07 \%$ and $0.63 \pm$ $0.04 \%$, respectively. An effect of acid strength on the TOC values is clearly visible between 0.2 and $1.5 \mathrm{~mol} \mathrm{~L}^{-1} \mathrm{HCl}$ acid treatment, where we can observe a decreasing trend from values around $0.8 \%$ down to $0.6 \%$ (Figure $2 \mathrm{~A}$ ). This loss of $0.2 \%$ of the TOC is accompanied by an increase of $1.5 \%$ in the $\delta^{13} \mathrm{C}_{\text {org }}$ values (from $-25.6 \%$ to $24.1 \%$ ), explaining the slightly higher standard deviation obtained for these two samples (Figure 2B). Above $1.5 \mathrm{~mol} \mathrm{~L}^{-1} \mathrm{HCl}$ acid concentration, neither $\mathrm{OC}$ content nor isotopic ratios present any trends. Interestingly, the TOC and isotopic ratios are not affected by the type of acid used for the decarbonation step (i.e. $\mathrm{HCl}$ or $\mathrm{AA}$ ): the $A A$ values (both $T O C$ and isotopic ratios) are similar to those obtained from $\mathrm{HCl}$ treatment above $1.5 \mathrm{~mol} \mathrm{~L}^{-1}$ for these two samples.

The interglacial sediment sample, S157, thus shows higher TOC and higher $\delta^{13} \mathrm{C}_{\text {org }}$ values than the two glacial samples, S305 and $\mathrm{S} 102(0.8$ vs $0.6 \%$ on average, and $-22.0 \%$ vs $-24.5 \%$ on average).

\subsection{Total nitrogen content and isotopic ratio}

The mean TN value for the three samples with the different decarbonatation methods is $0.08 \pm 0.002 \%$ wt/wt (Table 1 ). The TN appears stable and low whatever the climatic context. The $\delta^{15} \mathrm{~N}_{\text {tot }}$ values obtained during this study show homogeneous values with a global average of $3.0 \pm 0.1 \%$, with no significant influence of the acid strength on the isotopic ratio (Figures $2 \mathrm{D}$ and $2 \mathrm{E}$ ). Therefore, the TN and the isotopic ratio do not appear to be sensitive to the type of acid used.

\section{3. $\mathrm{C} / \mathrm{N}$ ratios}

The $\mathrm{C} / \mathrm{N}$ ratios obtained on interglacial samples show an average value of $10.0 \pm 0.3$, which is typical of marine particulate OM (a broad term used for phytoplankton and zooplankton OM; (23) and references therein). 
The $\mathrm{C} / \mathrm{N}$ ratios obtained on glacial samples (i.e. S304 and S102) show an average value of $8.0 \pm 0.8$. The high variability observed, up to $30 \%$ in the two glacial samples, is due a decrease of the $\mathrm{C} / \mathrm{N}$ ratios with increasing acid strength (from 10.5 to 7.5 for S304 and from 9.5 to 7 for S102, Figure 2C). For acid strength over $1.5 \mathrm{~mol}$ $\mathrm{L}^{-1} \mathrm{HCl}$, the $\mathrm{C} / \mathrm{N}$ ratios do not show significant variations.

\section{Discussion}

Decarbonatation is a necessary step to remove all carbonate (IC) phases from samples before measuring the content and isotopic composition of the $\mathrm{OC}$ pool in sediments. In agreement with the data obtained in this study, no clear effect of the acid strength is observed on TN and isotopic composition, (Figures 2D and 2E). This is surprising in the sense that nitrogen is usually considered as affected by acid treatment during the removal of labile proteins. Our results suggest that the pool of leachable organic matter does not contain so much nitrogen, perhaps because sediments have already experienced a first diagenetic effect that mineralised most of the $\mathrm{N}$-rich labile proteins. In the light of these results for the nitrogen content and isotopic ratios, no further consideration on nitrogen will be addressed in this part of the Discussion. Below we discuss first the Glacial-Interglacial discrepancies of the sediment, which should have led to different acid attack response, then the presence of a leachable pool of Organic Carbon.

\subsection{Glacial vs Interglacial samples geochemical response}

A clear distinction between glacial (i.e. S102 and S304) and interglacial (i.e. S157) samples can be observed in Figure 2. Indeed, the carbon isotopic composition and TOC of the interglacial sample do not seem to be affected by the pre-treatment acidification, whereas glacial samples show a clear change in response to the acid strength between 0.2 and $1.5 \mathrm{~mol} \mathrm{~L}^{-1}$. This different geochemical response may reflect different properties of the sediment, including different sources and reactivities of the sedimentary OM towards acid treatment. Differences in the physical sediment properties between glacial and interglacial sediments have been highlighted in previous studies of PRGL_1-4 (22). In the GoL shelf, glacial interglacial variations are characterized by substantial glacio-eustatic movements inducing migration of the coastline, and associated rivers (i.e. Rhône and Pyrenean rivers). 
Lower sea level during glacial times induced a seaward migration of the coast that brought the borehole location closer to the source of terrestrial materials (i.e. river mouths). This proximal environment is characterized by greater inputs of fresh terrestrial $\mathrm{OM}$ and deposition of low porosity silty-clay material. A higher proportion of fresh terrestrial $\mathrm{OM}$ is buried into the sediment with limited degradation by oxic respiration $(22,26)$.

In contrast, interglacial times are associated with higher temperature, higher sea level and a disconnection of coastal river from our site location. This is supported by an increase of $\delta^{13} \mathrm{C}_{\text {org }}$ values, indicative of higher marine inputs. Coastal rivers disconnection and high sea level are typically accompanied by lower sedimentation rates together with an increase of the porosity due to high foraminifera abundance. We propose that these changes increase oxygen diffusion depth into the sediment, which favoured aerobic respiration of the OM. Consequently, a lower proportion of reactive OM remains within the sediment.

We thus propose that glacial samples S102 and S304 may have preserved a higher proportion of $\mathrm{OM}$ including an acid leachable pool. This preservation may be linked to both physical sediment properties and sedimentation rates, which influenced early diagenesis processes. We highlight here that different samples with distinct pools of OM react differently to the acid attack.

\subsection{A weak $\mathrm{HCl}$ acid attack resistant pool of Carbon}

For glacial samples S304 and S102, the negative covariation observed between TOC and $\delta^{13} \mathrm{C}_{\text {org }}$ values strongly suggests a loss of carbon with a different isotopic ratio. The effect of the exposure to concentrated or diluted $\mathrm{HCl}$ on the $\mathrm{TOC}$ is clearly visible in Figures $2 \mathrm{~A}$ and $2 \mathrm{~b}$, where the TOC content shifted from 0.8 to $0.6 \%$. Strong acids (above $1,5 \mathrm{~mol} \mathrm{~L}^{-1} \mathrm{HCl}$ ) allow the removal of at least $25 \%$ of the OM compared with our lowest acid treatment $\left(0.2 \mathrm{~mol} \mathrm{~L}^{-1}\right)$. It appears that the loss is greater as the acid strength increase.

One hypothesis would be that the carbonate phases were not completely dissolved or that another resistant carbonate phase was present as proposed by (13) or (24). Indeed, it has been shown that some magnesium or iron carbonates, such dolomite or siderite, can resist acid treatment at $25^{\circ} \mathrm{C}$ for hours (25). Interestingly, this decrease in $\mathrm{OM}$ content is concomitant with an increase in $\delta^{13} \mathrm{C}_{\text {org }}$ values, 
(Figures $2 \mathrm{~A}$ and $2 \mathrm{~B}$ ). This suggest that the $25 \%$ pool of OM removed by strong acid is enriched in ${ }^{12} \mathrm{C}$ with a $\delta^{13} \mathrm{C}$ value lower than $-25 \%$ (Figure 2B). Such a pool with a low $\delta^{13} \mathrm{C}$ value is incompatible with the remaining carbonate phase $(26,27)$.

Moreover, the loss of isotopically light organic carbon seems proportional to the strength of $\mathrm{HCl}$ between 0.2 to $1.5 \mathrm{~mol} \mathrm{~L}^{-1}$. Above $1.5 \mathrm{~mol} \mathrm{~L}^{-1}$, this leaching of isotopically light $\mathrm{OC}$ seems complete and both isotopic and content values are stable.

3.3. An isotopically light terrestrial organic matter leachable pool at $\mathrm{HCl}$ strength above $1.5 \mathrm{~N}$

In the GoL, the glacial sediments are mostly composed of homogenous clastic material with OM spots mainly exported from fresh and labile land OM, such as wood and leaf fragments, with carbon isotopic ratios ranging from $-32 \%$ to $-21 \%$ (28). Therefore, the loss of terrestrial labile fine organic materials during increased $\mathrm{HCl}$ strength treatment could bias the natural sedimentary mixing and explain the observed dataset.

In the GoL watershed and prodeltaic sedimentary accumulation, the TOC content and the $\delta^{13} \mathrm{C}_{\text {org }}$ of bulk OM from river beds have revealed values around $1.5 \%$ and $-27 \pm 1 \%$, respectively $(1,2)$. To test our assumption of preferential leaching of terrestrial fresh $\mathrm{OM}$, we used a linear mixing extrapolation to confirm the removal of terrestrial OM (Figure 3). Effectively, in a $\delta^{13} \mathrm{C}_{\text {org }}$ vs $1 /$ TOC plot (Figure 3 ) we can see that the obtained data are aligned between (1) a terrestrial OC from the catchment area and (2) a stable mix between marine primary production (and subsequent derived-products) and detrital OM.

First, this trend confirms the main terrestrial origin of our samples. Furthermore, a close examination of this Figure allows us to observe the influence of acid strength on the proportion of terrestrial organic carbon preserved in our glacial samples. These results indicate that a small but isotopically important proportion of the terrestrial organic carbon is preferentially lost during decarbonatation. In landderived sediments the OM is composed of a vast pool of organic molecules that can be resistant to weak acid conditions. For example, in soils where the $\mathrm{pH}$ can decrease strongly, humic acid has been shown to be a significant component of the OC pool, which moreover has low $\delta^{13} \mathrm{C}_{\text {org }}$ values $(1,29,30)$. In such a context, we 
suggest that there is preferential leaching of the organic acid compounds during the decarbonatation step. Nevertheless, a careful investigation of the effect of the acid strength on the organic acid fraction is necessary to confirm this hypothesis.

\subsection{Impact of acid treatment on $\mathbf{C} / \mathrm{N}$ ratios and interpretation.}

$\mathrm{C} / \mathrm{N}$ ratios are indicators for $\mathrm{OM}$ source; when combined with $\delta^{13} \mathrm{C}_{\text {org }}$ values in a cross plot, they are commonly used to distinguish terrestrial (C3 vs C4 land plants) and aquatic (marine vs fresh water) sources $(23,31)$. Figure 4 shows a classical biplot used for paleo environment reconstruction. It clearly indicates procedural bias on the data that is equal in magnitude to the difference between terrestrial and marine environment. We note that the bias in the $\mathrm{C} / \mathrm{N}$ ratio is concomitant with the isotopic offset reported in this study, highlighting the clear leaching of labile terrestrial OM preserved in coastal marine sediments.

\section{Summary and conclusions}

We evaluated the effect of acid strength on recent geological sediment samples from a coastal environment by comparing different acid treatment methods (i.e. $\mathrm{HCl}$ and $\mathrm{AA}$ ) during the decarbonatation step prior to TOC, TN, $\delta^{15} \mathrm{~N}$ and $\delta^{13} \mathrm{C}_{\text {org }}$ measurements. We summarize the main findings in the following points:

$1 /$ We identified that the TOC, TN, $\delta^{15} \mathrm{~N}$ and $\delta^{13} \mathrm{C}_{\text {org }}$ values do not show significant variability when using strong $\left(>1.5 \mathrm{~mol} \mathrm{~L}^{-1}\right) \mathrm{HCl}$ or $\mathrm{AA}$ treatment.

2/ Weak $\mathrm{HCl}$ acid treatment $\left(<1.5 \mathrm{~mol} \mathrm{~L}^{-1}\right)$ in the Glacial samples shows systematically higher TOC together with lower $\delta^{13} \mathrm{C}_{\text {org }}$ values. Strong $\mathrm{HCl}$ acid and acetic acid treatments remove a distinct pool of isotopically light $\mathrm{OM}$, which correspond to a $25 \%$ loss of the TOC.

3/ This effect depends on the lithology and is only seen in samples containing high terrestrial source organic matter. It does not affect the nitrogen content nor the nitrogen isotopic ratio.

4/ Variations observed in the TOC, $\delta^{13} \mathrm{C}_{\text {org }}$ values and $\mathrm{C} / \mathrm{N}$ ratio after the different acid pre-treatment protocols are sufficient to affect any interpretations of organic carbon sources (Figure 4). 
These results call for more precautions when using classic acid treatment for sediments. It is highly probable that this pool, which is leached by acetic acid and hydrochloric acid up to $1.5 \mathrm{~mol} \mathrm{~L}^{-1}$, is naturally removed during late diagenesis in old sediments. This mean that for old rocks the main problem would be to remove the IC fraction entirely and thus strong acid treatment is recommended. However, for modern sediments the situation is different. The presence of such a pool could represent a major problem for paleo environment interpretation. The weak acid treatment commonly used for modern sediments (23 and references within) may induce a large bias. Variations in $\delta^{13} \mathrm{C}_{\text {org }}$ values measured on organic matter that experienced such acid treatment could represent different proportions of this weakacid leachable organic pool over the total OM reservoir. It is thus essential to test different acid treatments on the main lithologies before any systematic down core study.

\section{Acknowledgements}

This work was supported by the "Laboratoire d'Excellence" LabexMER (ANR10-LABX-19) and co-funded by a grant from the French government under the program "Investissements d'Avenir", and by a grant from the Regional Council of Brittany. Additional founding came from Actions Marges Program (Mediterranean Sea). The drilling operation was conducted within the European Commission Project PROMESS (contract EVR1-CT-2002-40024). The European Promess Scientific committee and colleagues at Ifremer are also thanked for previous contributions of data acquisition, processing, interpretations and permitting to re-sample the borehole. 


\section{References:}

1. Tesi T, Miserocchi S, Goñi MA, Langone L. Source, transport and fate of terrestrial organic carbon on the western Mediterranean Sea, Gulf of Lions, France. Mar. Chem. 2007;105:101-17.

2. Kim JH, Schouten S, Buscail R. Origin and distribution of terrestrial organic matter in the NW Mediterranean (Gulf of Lions): Exploring the newly developed BIT index. Geochem. Geophys. 2006;7(11):1-20.

3. Cathalot $C$, Rabouille $C$, Pastor L, Deflandre B. Temporal variability of carbon recycling in coastal sediments influenced by rivers: assessing the impact of flood inputs in the Rhône River prodelta. Biogeosciences. 2010;7:1187-205.

4. Tesi T, Langone L, Goñi MA, Wheatcroft RA, Miserocchi S, Bertotti L. Early diagenesis of recently deposited organic matter: A 9-yr time-series study of a flood deposit. Geochim. Cosmochim Acta. 2012;83(C):19-36.

5. Aller RC. Sedimentary Diagenesis, Depositional Environments, and Benthic Fluxes. 8 ed. Vol. 11, The Oceans and Marine Geochem. Elsevier Ltd; 2014. $42 \mathrm{p}$.

6. Meyers PA. Preservation of elemental and isotopic source identification of sedimentary organic matter. Chem. Geol. 1994;114:289-.

7. Ader M, Sansjofre P, Halverson GP, Busigny V, Trindade RIF, Kunzmann M, Nogueira A. Ocean redox structure across the Late Neoproterozoic Oxygenation Event: A nitrogen isotope perspective. Earth Planet. Sci. Lett. $2014 ; 396(C): 1-13$.

8. Voss M, Dippner JW, Montoya JP. Nitrogen isotope patterns in the oxygendeficient waters of the Eastern Tropical North Pacific Ocean. Deep Sea Research Part I. 2001;48:1905-21.

9. Möbius J, Lahajnar N, Emeis KC. Diagenetic control of nitrogen isotope ratios in Holocene sapropels and recent sediments from the Eastern Mediterranean Sea. Biogeosciences. 2010;7(11):3901-14.

10. Robinson RS, Kienast M. A review of nitrogen isotopic alteration in marine sediments. Paleoceanography. 2012;27:1-13.

11. Ader $M$, Thomazo C, Sansjofre $P$, Busigny $V$. Interpretation of the nitrogen isotopic composition of Precambrian sedimentary rocks: Assumptions and perspectives. Chem. Geol. 2016;429:93-110.

12. Hayes JM. Factors controlling $13 \mathrm{C}$ contents of sedimentary organic compounds: principles and evidence. Mar. Geol..1993;113:111-25.

13. Brodie CR, Leng MJ, Casford J, Kendrick CP. Evidence for bias in C and N concentrations and $\delta 13 \mathrm{C}$ composition of terrestrial and aquatic organic materials due to pre-analysis acid preparation methods. Chem. Geol. $2011 ; 282: 67-83$. 
14. Brodie CR, Casford J, Lloyd JM, Leng MJ. Evidence for bias in C/N, $\delta 13 \mathrm{C}$ and $\delta 15 \mathrm{~N}$ values of bulk organic matter, and on environmental interpretation, from a lake sedimentary sequence by pre-analysis acid methods. Quat. Sci. Rev. 2011;30.

15. Lorrain A, Savoye N, Chauvaud L, Paulet YM. Decarbonation and preservation method for the analysis of organic $\mathrm{C}$ and $\mathrm{N}$ contents and stable isotope ratios of low-carbonated suspended particulate material. Anal. Chim. Acta. 2003;491:125-33.

16. Schubert CJ, Nielsen B. Effects of decarbonation treatments on $\delta 13 \mathrm{C}$ values in marine sediments. Mar. Chem. 2000;72:55-9.

17. Ryba SA, Burgess RM. Effects of sample preparation on the measurement of organic carbon, hydrogen, nitrogen, sulfur, and oxygen concentrations in marine sediments. Chemosphere. 2002;48:139-47.

18. Froelich PN. Analysis of organic carbon in marine sediments. Limnol Oceanogr. 1980;25(3):564-72.

19. Rabineau M, Berné S, Aslanian D, Olivet JL. Sedimentary sequences in the Gulf of Lion: a record of 100,000 years climatic cycles. Mar. Petr. Geol.. 2005;22:775-804.

20. Jouet G, Berné S, Rabineau M, Bassetti MA, Bernier P. Shoreface migrations at the shelf edge and sea-level changes around the Last Glacial Maximum (Gulf of Lions, NW Mediterranean). Mar. Geol. 2006;234:21-42.

21. Radakovitch $\mathrm{O}$, Charmasson $\mathrm{S}$, Arnaud M. $210 \mathrm{~Pb}$ and caesium accumulation in the Rhône delta sediments. Estuar. Coast. Shelf Sci. 1999;48:77-92.

22. Pasquier V, Sansjofre $P$, Rabineau M. Pyrite sulfur isotopes reveal glacialinterglacial environmental changes. Proc. Natl. Acad. Sci. 2017;117(23):59415945.

23. Lamb AL, Wilson GP, Leng MJ. A review of coastal palaeoclimate and relative sea-level reconstructions using $\delta 13 \mathrm{C}$ and $\mathrm{C} / \mathrm{N}$ ratios in organic material. Earth Sci. Rev. 2006;75:29-57.

24. Kolasinski J, Rogers K, Frouin P. Effects of acidification on carbon and nitrogen stable isotopes of benthic macrofauna from a tropical coral reef. Rapid Commun. Mass Spectrom. 2008;22:2955-2960.

25. Lebeau O, Busigny V, Chaduteau C, Ader M. Organic matter removal for the analysis of carbon and oxygen isotope compositions of siderite. Chem. Geol. 2014;372:54-61.

26. Sierro FJ, Andersen N, Bassetti MA, Berné S. Phase relationship between sea level and abrupt climate change. Quat. Sci. Rev. 2009;28:2867-2881.

27. Cortina A, Sierro FJ, Gonzalez-Mora B, Asioli A. Impact of climate and sea level changes on the ventilation of intermediate water and benthic foraminifer 
assemblages in the Gulf of Lions, off South France, during MIS 6 and 7. Palaeogeogr. Palaeoclimatol. Palaeoecol. 2011;309:215-28.

28. Khan NS, Vane $\mathrm{CH}$, Horton BP. Stable carbon isotope and $\mathrm{C} / \mathrm{N}$ geochemistry of coastal wetland sediments as a sea-level indicator. Handbook of Sea-Level Research. 2015;1:295-311.

29. Hood E, Williams MW, McKnight DM. Sources of dissolved organic matter (DOM) in a Rocky Mountain stream using chemical fractionation and stable isotopes. Biogeochem. 2005;74:231-55.

30. Giani M, Rampazzo F, Berto D. Humic acids contribution to sedimentary organic matter on a shallow continental shelf (northern Adriatic Sea). Estuar. Coast. Shelf Sci.. 2010;90(2):103-10.

31. Meyers PA. Organic geochemical proxies of paleoceanographic, paleolimnologic, and paleoclimatic processes. Org. Geochem. 1997;27(5/6):213-50.
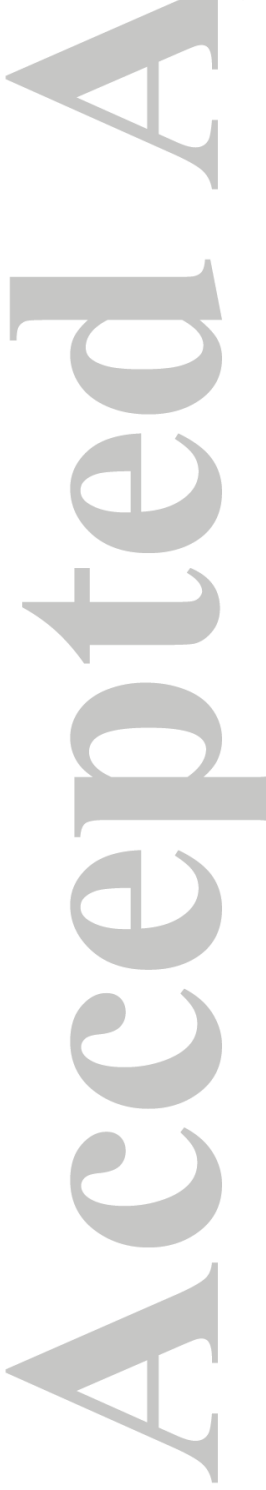
Table 1: Nitrogen stable isotopes $\left(\delta^{15} \mathrm{~N}\right)$ Organic carbon stable isotope $\left(\delta^{13} \mathrm{C}_{\text {org }}\right)$; concentration of total nitrogen (TN); concentration of total organic carbon (TOC), and atomic $\mathrm{C} / \mathrm{N}$ ratio reported against different acid type and concentration used during the pre-analyses treatment of three different layers of PRGL_1-4 borehole. According to the age model published in (22), S.304 and S.102 are glacial samples whereas S.157 corresponds to interglacial conditions.

\begin{tabular}{|c|c|c|c|c|c|c|}
\hline Sample & Acid Strengh & $\begin{array}{c}\boldsymbol{\delta} 15 \text { Ntot } \\
(\%)\end{array}$ & $\begin{array}{c}\boldsymbol{\delta} 13 \text { Corg } \\
(\%)\end{array}$ & $\begin{array}{l}\mathrm{TN} \\
(\%) \\
\end{array}$ & $\begin{array}{c}\text { TOC } \\
(\%)\end{array}$ & $\mathrm{C} / \mathrm{N}$ \\
\hline & $0.2 \mathrm{~N} \mathrm{HCl}$ & 3.5 & -25.2 & 0.08 & 0.79 & 10.40 \\
\hline & $0.5 \mathrm{~N} \mathrm{HCl}$ & 3.7 & -25.1 & 0.08 & 0.75 & 9.81 \\
\hline & $1 \mathrm{~N} \mathrm{HCl}$ & 3.2 & -24.8 & 0.07 & 0.64 & 8.97 \\
\hline & $1.5 \mathrm{~N} \mathrm{HCl}$ & 3.4 & -25.0 & .08 & 0.67 & 8.85 \\
\hline & $2 \mathrm{~N} \mathrm{HCl}$ & 3.4 & -24.8 & 0.07 & 0.62 & 8.39 \\
\hline & $2.5 \mathrm{~N} \mathrm{HCl}$ & 3.4 & -24.3 & 0.07 & 0.58 & 7.84 \\
\hline & $3 \mathrm{~N} \mathrm{HCl}$ & 3.4 & -24.3 & 0.07 & 0.60 & 8.11 \\
\hline & $4 \mathrm{~N} \mathrm{HCl}$ & 3.1 & -24.3 & 0.07 & 0.56 & 7.83 \\
\hline & $5 \mathrm{~N} \mathrm{HCl}$ & 3.5 & -24.4 & 0.08 & 0.60 & 8.01 \\
\hline & $6 \mathrm{~N} \mathrm{HCl}$ & 3.2 & -24.5 & 0.07 & 0.58 & 7.87 \\
\hline & $7 \mathrm{~N} \mathrm{HCl}$ & 3.3 & -24.4 & 0.07 & 0.59 & 8.04 \\
\hline & $8 \mathrm{~N} \mathrm{HCl}$ & 3.1 & -24.5 & 0.07 & 0.57 & 8.03 \\
\hline & $9 \mathrm{~N} \mathrm{HCl}$ & 3.2 & -24.4 & 0.07 & 0.58 & 8.02 \\
\hline & $10 \mathrm{~N} \mathrm{HCl}$ & 3.3 & -24.6 & 0.07 & 0.61 & 8.21 \\
\hline & $10 \mathrm{~N} \mathrm{HCl}$ & & & & & \\
\hline & $+80^{\circ} \mathrm{C}$ & 3.2 & -24.7 & 0.08 & 0.72 & 9.45 \\
\hline & $0.2 \mathrm{~N} \mathrm{HCl}$ & 3.2 & -25.4 & 0.08 & 0.76 & 9.21 \\
\hline & $0.5 \mathrm{~N} \mathrm{HCl}$ & 3. & -24.8 & 0.09 & 0.69 & 7.96 \\
\hline & $1 \mathrm{~N} \mathrm{HCl}$ & 3.1 & -24.3 & 0.08 & 0.63 & 7.70 \\
\hline & $1.5 \mathrm{~N} \mathrm{HCl}$ & 2.9 & -24.2 & 0.08 & 0.63 & 7.64 \\
\hline & $2 \mathrm{~N} \mathrm{HCl}$ & 2.9 & -24.4 & 0.08 & 0.62 & 7.55 \\
\hline & $2.5 \mathrm{~N} \mathrm{HCl}$ & 3.0 & -24.3 & 0.08 & 0.61 & 7.58 \\
\hline & $3 \mathrm{~N} \mathrm{HCl}$ & 3.1 & -24.2 & 0.08 & 0.62 & 7.37 \\
\hline & $4 \mathrm{~N} \mathrm{HCl}$ & 3.0 & -24.0 & 0.08 & 0.62 & 7.32 \\
\hline & $5 \mathrm{~N} \mathrm{HCl}$ & 3.1 & -24.4 & 0.09 & 0.61 & 7.03 \\
\hline & $6 \mathrm{~N} \mathrm{HCl}$ & 3.0 & -24.1 & 0.08 & 0.6 & 7.10 \\
\hline & $7 \mathrm{~N} \mathrm{HCl}$ & 3.1 & -24.3 & 0.08 & 0.58 & 6.88 \\
\hline & $8 \mathrm{~N} \mathrm{HCl}$ & 3.0 & -24.2 & 0.0 & 0.61 & 7.14 \\
\hline & $9 \mathrm{~N} \mathrm{HCl}$ & 3.1 & -24.2 & 0.08 & 0.59 & 7.02 \\
\hline & $10 \mathrm{~N} \mathrm{HCl}$ & 3.2 & -24.1 & 0.09 & 0.0 & 7.05 \\
\hline & $10 \mathrm{~N} \mathrm{HCl}$ & & & & & \\
\hline & $+80^{\circ} \mathrm{C}$ & 2.7 & -24.1 & 0.08 & 0.66 & 8.23 \\
\hline & $5 \% A A$ & 3.0 & -24.3 & 0.08 & 0.65 & 7.82 \\
\hline
\end{tabular}




\begin{tabular}{|c|c|c|c|c|c|c|}
\hline & $10 \% A A$ & 3.0 & -24.1 & 0.08 & 0.62 & 7.54 \\
\hline & $0.2 \mathrm{~N} \mathrm{HCl}$ & 2.9 & -22.1 & 0.08 & 0.75 & 9.51 \\
\hline & $0.5 \mathrm{~N} \mathrm{HCl}$ & 2.6 & -22.3 & 0.08 & 0.77 & 10.05 \\
\hline & $1 \mathrm{~N} \mathrm{HCl}$ & 2.7 & -21.9 & 0.09 & 0.84 & 9.65 \\
\hline & $1.5 \mathrm{~N} \mathrm{HCl}$ & 2.8 & -22.0 & 0.09 & 0.84 & 9.60 \\
\hline & $2 \mathrm{~N} \mathrm{HCl}$ & 2.8 & -22.0 & 0.08 & 0.82 & 10.15 \\
\hline & $2.5 \mathrm{~N} \mathrm{HCl}$ & 2.9 & -22.2 & 0.07 & 0.74 & 10.01 \\
\hline & $3 \mathrm{~N} \mathrm{HCl}$ & 2.9 & -22.2 & 0.09 & 0.83 & 9.62 \\
\hline S.157 & $4 \mathrm{~N} \mathrm{HCl}$ & 2.9 & -22.1 & 0.08 & 0.78 & 9.72 \\
\hline & $5 \mathrm{~N} \mathrm{HCl}$ & 2.6 & -22.1 & 0.08 & 0.5 & 9.80 \\
\hline & $6 \mathrm{~N} \mathrm{HCl}$ & 2.7 & -22.1 & 0.08 & 0.78 & 10.06 \\
\hline & $7 \mathrm{~N} \mathrm{HCl}$ & 2.9 & -22.1 & 0.08 & 0.80 & 9.82 \\
\hline & $8 \mathrm{~N} \mathrm{HCl}$ & .7 & -22.1 & 0.08 & 0.80 & 10.14 \\
\hline & $9 \mathrm{~N} \mathrm{HCl}$ & 2.6 & -21.7 & 0.08 & 0.80 & 10.37 \\
\hline & $10 \mathrm{~N} \mathrm{HCl}$ & 2.8 & -22.2 & 0.08 & 0.82 & 10.22 \\
\hline & $10 \mathrm{~N} \mathrm{HCl}$ & & & & & \\
\hline & $+80^{\circ} \mathrm{C}$ & 2.6 & -22.0 & 0.07 & 0.80 & 10.76 \\
\hline & $5 \% A A$ & 2.7 & -21.9 & 0.08 & 0.78 & 10.26 \\
\hline & $10 \%$ AA & 2.8 & -21.9 & 0.08 & 0.74 & 9.84 \\
\hline
\end{tabular}




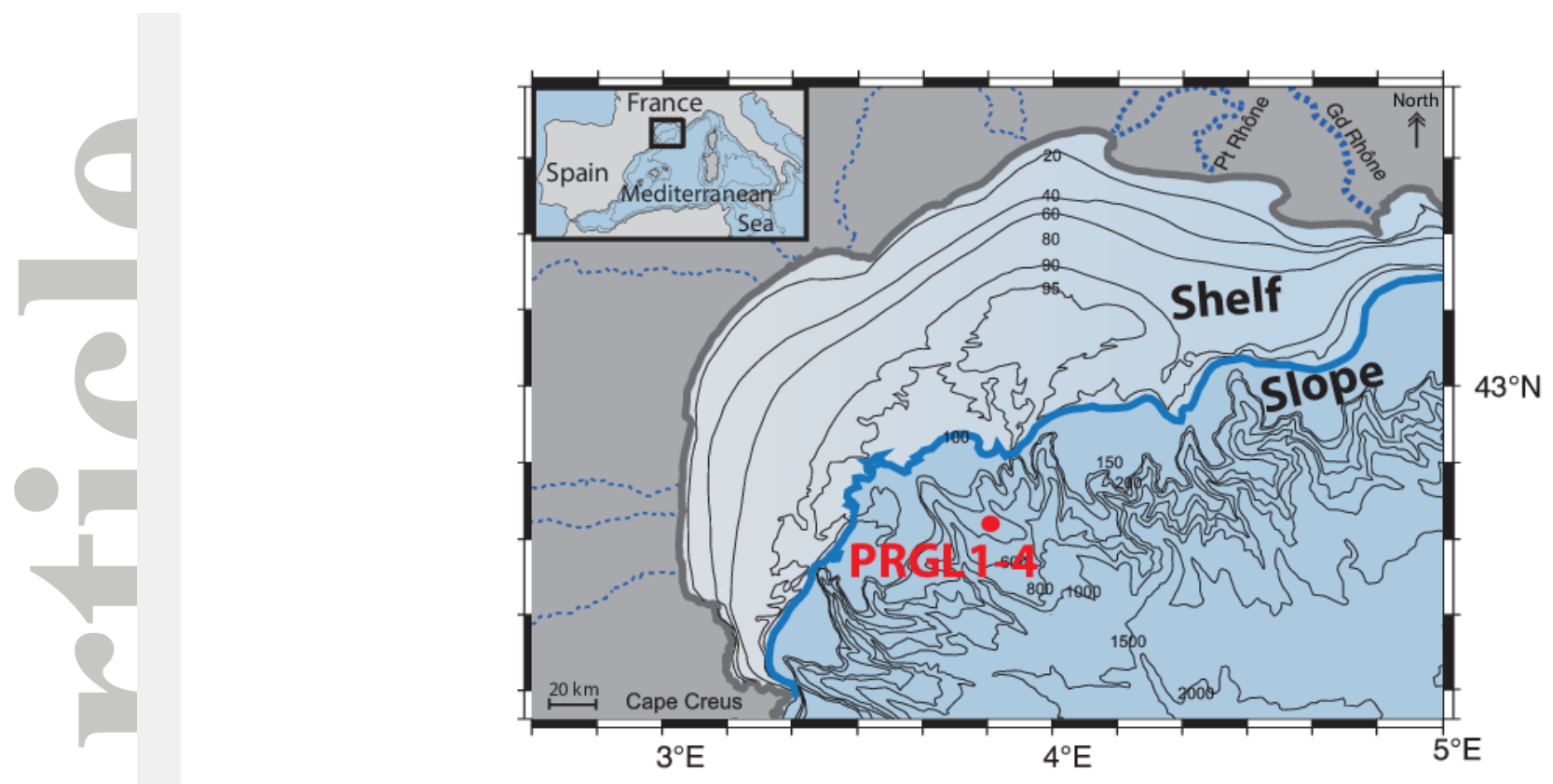

Pasquier et al., Figure 01

Figure 1: Map of the Gulf of Lion with the position of the PRGL1-4 core $(42.690 \mathrm{~N} ; 3.838 \mathrm{E})$. The bold grey line highlights the present shoreline position and the contours reflect modern water depths. The bold blue line corresponds to the shoreline position during the last-glacial period (low sea level). 


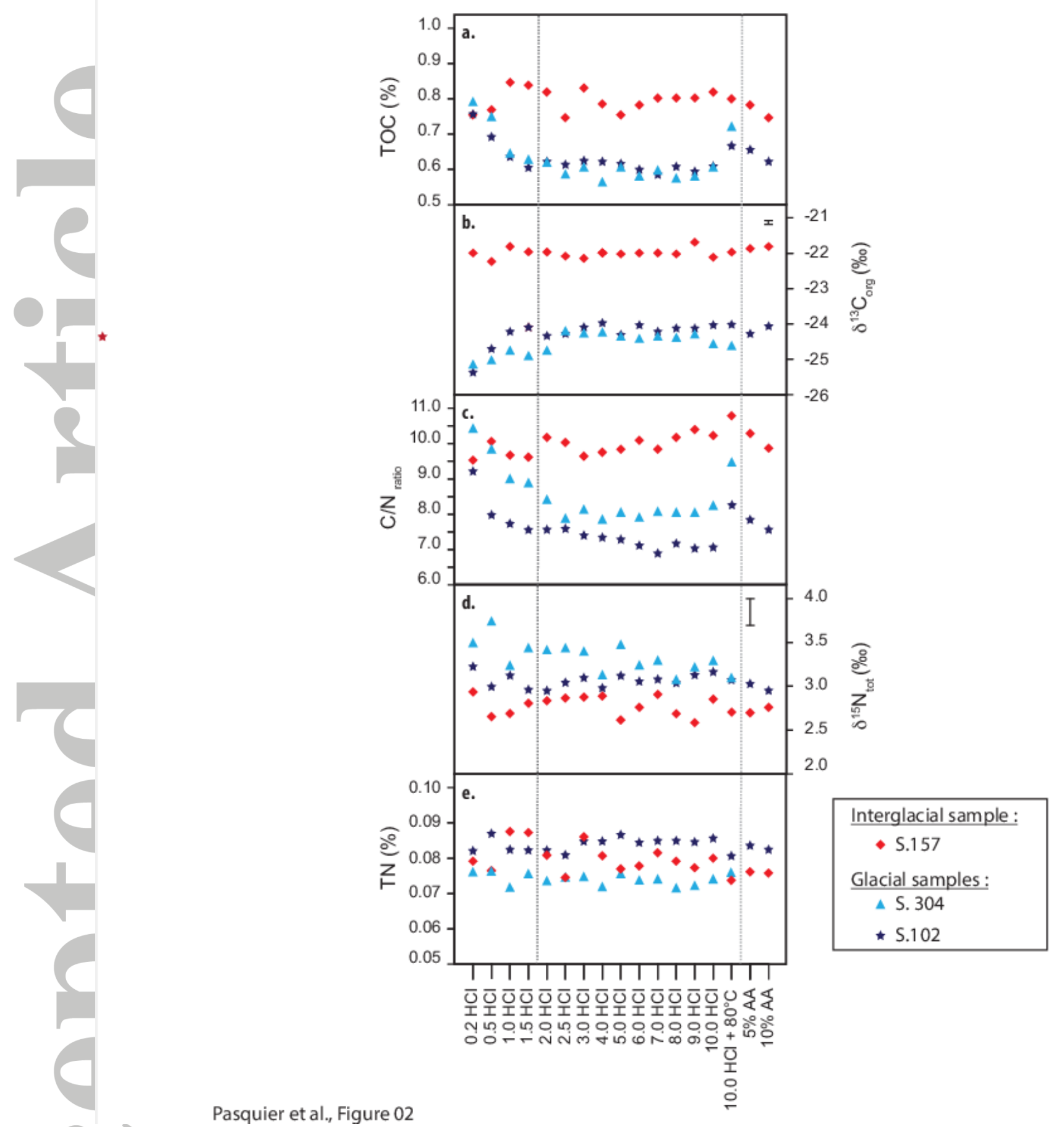

Figure 2: a. Percentage of total organic carbon (i.e.\% TOC wt/wt); b. Organic carbon isotopic (i.e. $\delta^{13} \mathrm{C}_{\text {org }}$ ); c. $\mathrm{C} / \mathrm{N}$ ratio of preserved organic matter; $\mathbf{d}$. Nitrogen isotopic values; e. Percentage of total nitrogen (i.e. \%TN wt/wt). Symbol colours indicate various climatic context: red diamonds for interglacial times related to sample S.157 and light and dark blue symbols show glacial samples, S.304 and S.102, respectively. Data are presented as function of the acid type and strength used during the decarbonation step. Error bars obtained on isotopic measurements 
represent 1SD measured on certified material whereas for total organic carbon and total nitrogen the error bars are smaller than the dots size.

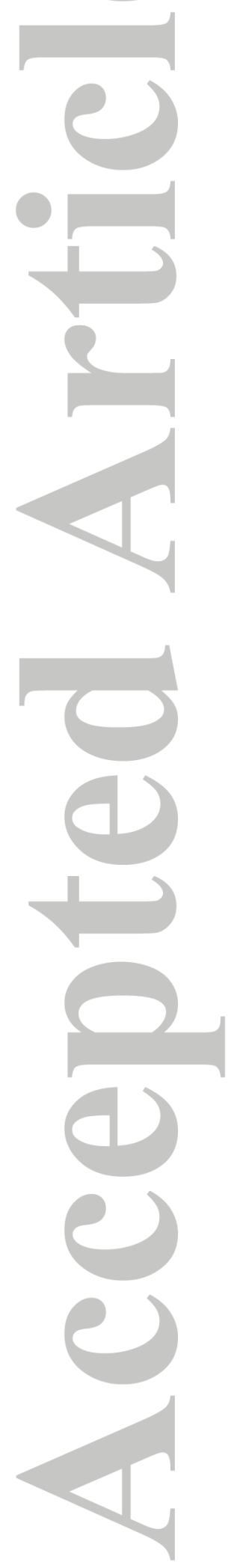


$1 /$ TOC

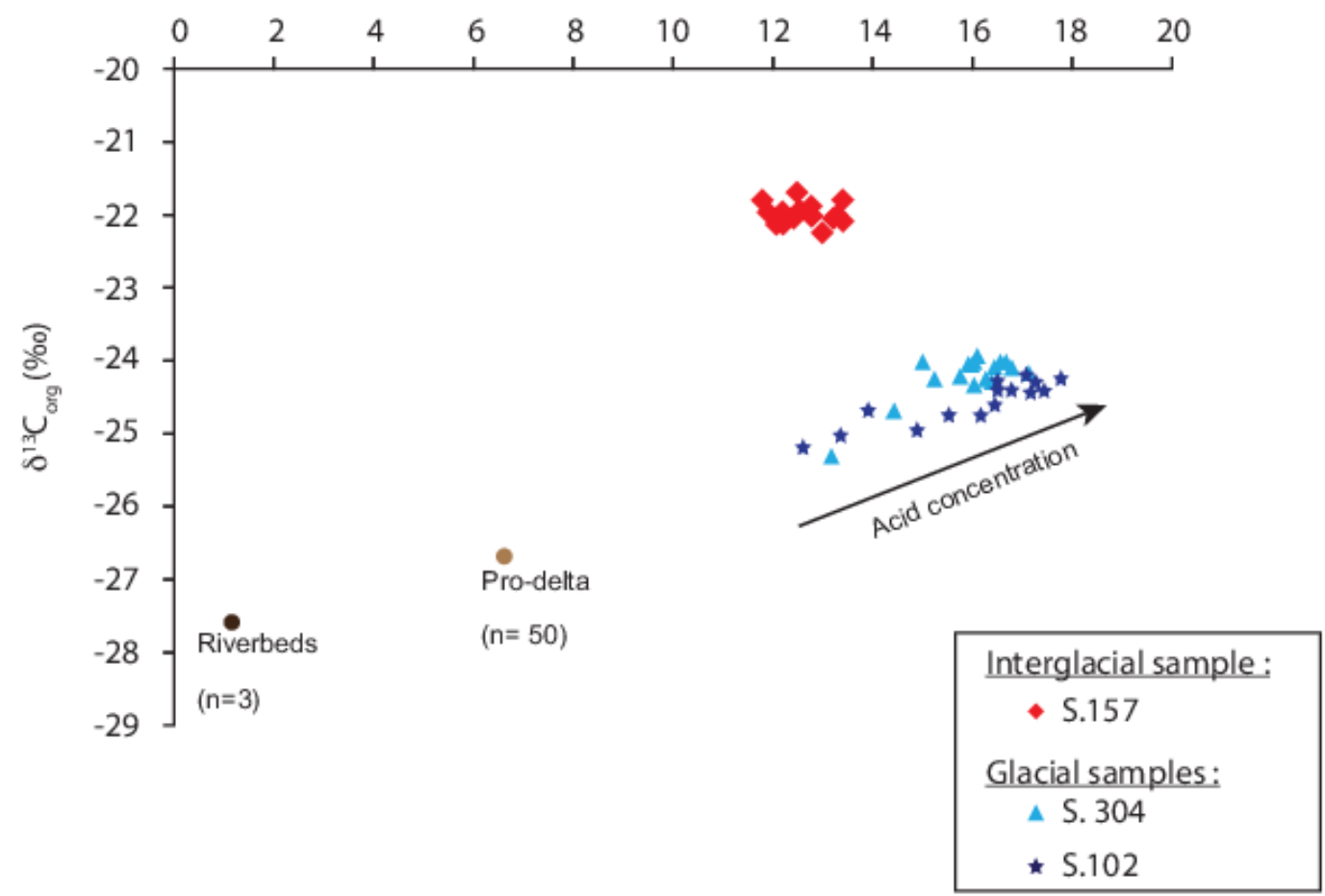

Pasquier et al., Figure 03

Figure 3: Linear mixing model showing a parental source between terrestrial derived riverbed/prodelta and the glacial samples of this study (blues symbols). Red diamonds correspond to interglacial samples S.157; light and dark blue symbols show data obtained on glacial samples S. 304 and S. 102, respectively. Error bars are smaller than the dots size. Pro-delta values from (1); River bed data from (2). 


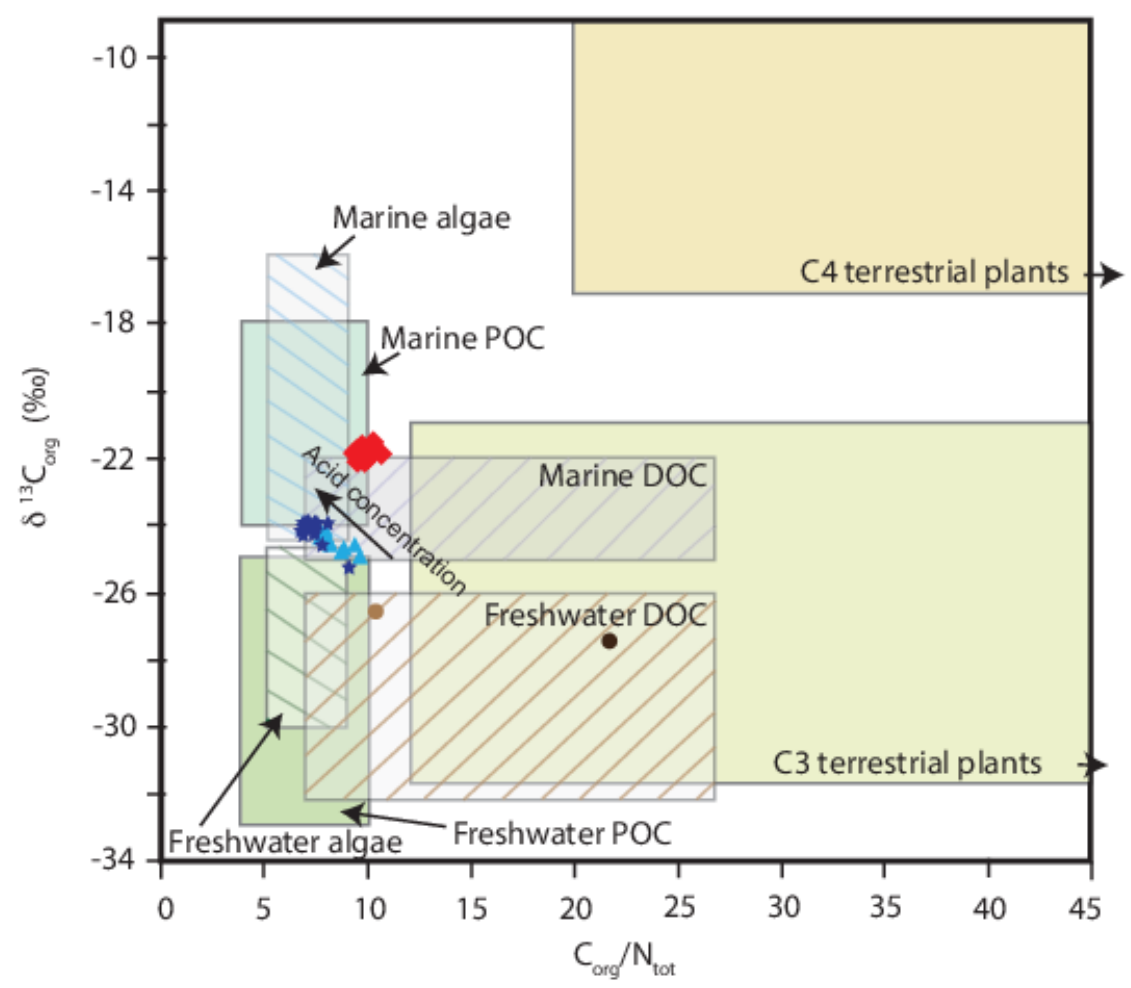

Pasquier et al., Figure 04

Figure 4: $\delta^{13} \mathrm{C}_{\text {org }}$ vs $\mathrm{C} / \mathrm{N}$ ratio currently used to determine the OM provenance. Error bars are smaller than the dots size. Typical $\delta^{13} \mathrm{C}_{\text {org }}$ and $\mathrm{C} / \mathrm{N}$ ranges for organic inputs to coastal environments are compiled from (23) and references therein. Pro-delta values from (1) (light brown dot); River bed data from (2) (dark brown dot). Figure modified after (23). 